of essential significance to impart. This gives an impression of reserve and distinction to his work. The present eminence of American mathematicians in algebra owes not a little to his pioneering, to his excellent teaching and to his editorship-in-chief, for nearly twenty years, of the Annals of Mathematics, which in 1911 became the charge of the Department of Mathematics at Princeton, and steadily rose to its present distinguished position among the mathematical periodicals of the world. The volume of the Annals published in 1946 was in effect a Festschrift dedicated to him. This may be taken as an indication of the respect in which he was held, not only by mathematicians in the United States, but also by mathematicians everywhere.

A. C. Airken

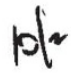

\section{Dr. George Scott Robertson}

George ScotT Robertson, permanent secretary of the Ministry of Agriculture, Northern Ireland, died on December 22.

Although his family had been closely associated with Aberdeen ton long period, he was born in 1893 in Middlesbrowgh, where his father, William Robertson, wa f Im many years editor of the North Eastern Deily Gquette. Robertson graduated B.Sc. (Agr.) at Arratreng College, University of Durham, and spent two years there as lecturer in agricultural chemistry. In 1914 he became head of the Chemistry Department of the East Anglian Institute of Agriculture, and in 1920 lecturer in agricultural chemistry at Queen's University, Belfast. A year after going to Northern Ireland he received, for his work on basic slag and rock phosphates, the first D.Sc. degree ever conferred by the University of Durham in its Faculty of Agriculture.

When the Government of Northern Ireland was formed, Robertson's inspiration and drive resulted in the creation of the Faculty of Agriculture in Queen's University, Belfast, which developed in the closest association with the Ministry of Agriculture, Northern Ireland. By 1924 he was professor of agricultural chemistry and dean of the Faculty, as well as senior research officer of the Ministry of Agriculture. By 1933 he became permanent secretary of this Ministry, and for fifteen years directed the work of his Department in peace and war, and saw it grow from a comparatively small organisation into one which to-day touches almost every phase of the life of agricultural Ulster.

Robertson's reputation extended far beyond Northern Ireland. He served with distinction on the Empire Marketing Board, the Imperial Agricultural Bureau, the Food Investigation Board of the Depart. ment of Scientific and Industrial Research and the Agricultural Research Council. For many years he was closely identified with the work of Section M (Agriculture) of the British Association; owing to illness, his presidential address at the Brighton meeting last September was read by a colleague.

In 1947 a striking tribute was paid to him when he was invited to become the first director of the new Agricultural Production Division of the Food and Agriculture Organisation of the United Nations. Robertson was absent from Northern Ireland on this work during the greater part of 1947 , and when he returned to Belfast it was evident that his health had been impaired by the heavy work he had under. taken-a task superimposed on many years of active endeavour.
Robertson's great services to agriculture in Northern Ireland and in the furtherance of agricultural science throughout the world generally were recognized by Queen's University last year, when the degree of LL.D. (honoris causa) was conferred upon him.

His publications include "Basic Slags and Rock Phosphates" (1922) and many other contributions to scientific journals. His main research work was concerned with phosphatic fertilizers in Essex and later in Northern Ireland--investigations which were of outstanding importance and are quoted to-day as classics in their sphere-and pioneer work in collaboration with Sir John Boyd Orr on the mineral requirements of farm livestock.

Robertson was respected for his outstanding ability and qualifications as a leader by his colleagues. He was held in deep and abiding regard as a friend by very many who will mourn his loss.

J. HoustoN

\section{Louis Rapkine}

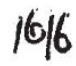

LouIS RAPKINE was born at Chichenich in White Russia on July 1404 . His father, who was a tailor, migrated ( Paris in 1911, taking his family with hign, ghduefter a difficult year, went to Montreal, where he 0 rked in a factory. Rapkine grew up as a dantian citizen. He gained his school education by scholarships. He was a good athlete, excelling in fetball and swimming. He spent three years at MdGill University, supporting himself by working in the summer vacations. When he was twenty, he left Canada to pursue scientific research in France.

Rapkine's scientific training was unusual, for he never took a doctorate. He worked in the laboratories of Caullery and Fauré-Fremiet, and in Wurmser's laboratory at the Institute of Physico-Chemical Biology. In France, at first, he had very meagre means of support. He kept himself by hawking in the countryside and selling boots at country fairs. Sometimes he starved, and was reduced to eating glucose from laboratory bottles.

In spite of these conditions, Rapkine did important work before he was twenty-one. With various collaborators, he published in 1925 extensive observa. tions on the hydrogen ion concentration in egg-cells by the micro-injection of dissolved indicators. $\mathrm{He}$ investigated the oxidation-reduction potentials of the nucleus and cytoplasm, and showed that the old idea that the nucleus was a special centre of oxidation was without foundation. His situation was relieved by the award of a Rockefeller fellowship in 1926. He found that the respiratory quotient for the echinoderm egg at four hours after fertilization was extremely high, and then slowed down. He concluded, contrary to Warburg and Shearer, that in the initial period oxidation-reduction was concerned with synthesis, and independent of respiratory processes. $\mathrm{He}$ published a monograph in 1928 on the energetics of the development of the egg. $\mathrm{He}$ pointed out that the developing organism may have at its disposal sources of energy other than complete combustion to carbon dioxide and water, and remarked that peak-protein catabolism coincides precisely with the stage of development at which chick embryos best provide plasma for tissue culture. In the same year, he was appointed assistant at the Institute of Physico-Chemical Biology, and afterwards received appointments from the Centre National de la Recherche Scientifique. 
Rapkine found that the fertilization of sea-urchin eggs was connected with changes in sulphydryl groups. Multiplication of cells depended on their presence. He was thus led to the study of enzymes. He found that the oxidation of sulphydryl groups was much more rapid when the enzymes were separated from their co-enzymes. He supposed that this was because the co-enzyme was attached to the enzyme in the region of sulphydryl groups, disturbing the access of oxidizing molecules.

The late Sir Frederick Gowland Hopkins had arrived at similar results in part of the sulphydryl work. When he heard of Rapkine's work, he withdrew, so that the younger man should be assured of priority.

By 1939 , after a hard struggle, Rapkine was scientifically established. He was thirty-five years old, and had arrived at about the same stage as Hopkins at a similar age. There were resemblances between them in unorthodoxy of career and quality of mind. He became a French citizen just before the Second World War. At the outbreak he was mobilized and sent to London to the office of the French coalimporting organisation, where he compiled statistics.

When France was invaded in 1940, Rapkine set himself to save French scientific workers from the enemy. He compiled a list of fifty-seven, whom he endeavoured to rescue. Without any authority other than his own character, he secured the support of the highest scientific and political personalities in London and Washington. He organised the escape of about forty leading scientific workers from France to the United States. He obtained posts for them, and even got their hospital bills paid.
In 1943 Rapkine negotiated an agreement with the British authorities for the establishment of a French Scientific Mission. $\mathrm{He}$ brought the group of French scientific workers in the United States to London to be its staff. This enabled France to receive during and after the liberation much new scientific knowledge and experience. As a consequence, a permanent secretary for Franco-British scientific exchanges was attached to the French Embassy in London. In recognition of this work, he was appointed a Chevalier of the Legion of Honour. Rapkine's last act as an administrator was to negotiate a donation of 350,000 dollars from the Rockefeller Foundation for the assistance of research in France.

Rapkine had revealed unique powers of leadership. Nevertheless, he hurried back to personal research. The Pasteur Institute created a Department of Cell Chemistry for him, and he threw himself passionately into its development. $\mathrm{H}_{\Theta}$ aimed at the solution of the mechanism of enzyme action. He believed that a single enzyme might be capable not only of one specification, but of many. He was organising a co-ordinated attack on this problem.

Rapkine's premature death, on December 13, is a disaster not only to his relatives and friends, but also to science, and to France. He had an extra. ordinary combination of moral strength, personal charm and intelligence, kindness, generosity and selflessness, besides practical and scientific ability. Many of those who knew him well regarded him as the finest man of his generation. His wife, who assisted him in his scientific work, and his daughter survive him.
J. G. Crowther

\section{NEWS and VIEWS}

\section{Recent Medal Awards: Geological Society of London}

THE Council of the Geological Society has announced the following awards: Wollaston Medal, to Dr. Robert Broom, in recognition of his researches in the field of vertebrate palæontology, especially in the study of the evolution of the reptiles and of the anthropoid apes and man; Murchison Medal, to Dr. E. M. Anderson, in recognition of his investigations of the igneous, metamorphic and stratigraphical geology of Scotland, and of his many original contributions in the field of geophysics; Lyell Medal, to Dr. W. J. Arkell, for his geological researches, especially on the stratigraphy, structure and palæontology of the Jurassic rocks of Great Britain ; Bigsby Medal, to Prof. W. Q. Kennedy, in recognition of his petrological researches and for his outstanding contri. butions in the field of tectonic geology; Wollaston Fund, to Mr. E. C. Martin, for his work on the Chalk Tertiary and Pleistocene succession in Sussex, and his valuable contribution to geological science as treasurer of the Geologists' Association for thirteen years, including the war years; Murchison Fund, to Dr. S. O. Agrell, for his work on the adinoles of Dinas Head, Cornwall, and his mineralogical observations on some basic open-hearth slags; a moiety of the Lyell Fund, to Dr. W. D. Evans, for his work on the Ordovician rocks of north Pembrokeshire, on air-borne dusts in collieries and on the
Midland iron-ore of coalfields; another moiety of the Lyell Fund, to Dr. P. E. Kent, for his geological investigations in East Africa and in the United Kingdom.

The Council

The Council of the Royal Astronomical Society has made tho following awards: Gold Medal to Prof. Sydney Chapman, Sedleian professor of natural philosophy in the University of Oxford, for his contributions to geophysies and solar physics, and particularly to the theory of geomagnetic phenomena ; Jackson-Gwilt Medal and Gift to Mr. Algernon Montague Newbegin, for his observations of solar prominences and sunspots during the past forty years.

\section{Institution of Mechanical Engineers}

THE James Watt International Medal of the Institution of Mechanical Engineers has been awarded to Dr. Predrik Ljungström, of Sweden, for his outstanding contributions to the development of mechanieal engineering, the most notable of which are the afr preheater which bears his name and the steam turbine developed jointly with his brother, the late Birger Ljungström. The Medal is awarded every two years to an engineer who has achieved worldwide eminence in some branch of mechanical engineering. 